\title{
EXTENDED TABLE OF CONTENTS
}

Preface

xxV

About the authors

$x \times v i i i$

List of figures

XXX

List of tables

$x x x i$

List of abbreviations

xxxii

Table of cases

xli

Table of legislation

xlvii

\section{PART I FINANCIAL COLLATERAL DIRECTIVE AND UK IMPLEMENTING REGULATIONS}

1. PURPOSE OF THE FINANCIAL COLLATERAL DIRECTIVE, THE LEGISLATIVE BACKGROUND AND KEY ISSUES ADDRESSED BY THE DIRECTIVE

A. PURPOSE OF THE FINANCIAL COLLATERAL DIRECTIVE $\quad 1.01$

1. Objective

1.01

2. Relevance of the legislative background

1.02

B. POSITION BEFORE THE FINANCIAL COLLATERAL DIRECTIVE

1.03

1. Need for reform

1.03

2. Cumbersome formalities for creating, perfecting and enforcing security collateral arrangements

3. Legal restrictions on use of collateral taken by way of security

4. Uncertainty regarding enforceability of title transfer collateral

5. Uncertainty as to conflict of laws rules

6. Vulnerability of title transfer collateral arrangements to the rights of third parties

7. Vulnerability of mark-to-market collateral arrangements

8. ISDA suggested principles for law reform

C. KEY QUESTIONS BEHIND THE FINANCIAL COLLATERAL DIRECTIVE

1. Action plan

2. Type of legal persons

3. Types of assets and exposure $\quad 1.38$

4. Title transfer and security $\quad 1.46$

5. Reuse of pledged collateral $\quad 1.52$

6. Substitution $\quad 1.56$

7. Netting 1.58

8. Cash 1.61

9. Top-up collateral $\quad 1.65$

10. Need for rapid liquidation $\quad 1.68$

11. Conflict of laws treatment of book entry securities $\quad 1.72$

$\begin{array}{ll}\text { 12. Territorial coverage } & 1.78\end{array}$

13. Abolishing administrative burdens through simplified perfection procedures $\quad 1.83$

14. Approach to be adopted by the new legislation $\quad 1.88$

$\begin{array}{lr}\text { 15. Choice of legislative measure } & 1.89\end{array}$

16. Matters outside the scope of the Directive $\quad 1.90$

D. ADDITION OF CREDIT CLAIMS AS A NEW CLASS OF COLLATERAL 1.91

$\begin{array}{ll}\text { 1. Increasing demand for collateral } & 1.91\end{array}$ 
2. Enlarging the pool of assets eligible as collateral 1.92

3. Proposal for a new Directive to amend the SFD and FCD 1.95

E. REVISITING THE RIGHT OF USE $\quad 1.102$

F. REVISITING CONFLICT OF LAWS $\quad 1.103$

1. Uncertainty concerning the location of the account 1.103

2. Hague Securities Convention 1.105

\section{SCOPE OF THE FINANCIAL COLLATERAL REGULATIONS}

A. APPROACH TO INTERPRETATION OF LEGISLATION IMPLEMENTING EU DIRECTIVES AND USE OF THE DIRECTIVE AND TRAVAUX PRÉPARATOIRES AS AN AID TO INTERPRETATION

1. Interpretation of EU Directives and implementing UK legislation 2.01

2. Autonomous meaning

B. FINANCIAL COLLATERAL REGULATIONS

1. Implementation of the Financial Collateral Directive in the UK 2.08

2. Territorial scope $\quad 2.09$

3. Types of entity to which the FCARs apply $\quad 2.15$

C. CHALLENGE TO THE VALIDITY OF THE FCARs $\quad 2.18$

1. Cukurova application for judicial review $\quad 2.18$

2. The United States of America v Nolan $\quad 2.29$

3. Enabling power to amend the FCARs $\quad 2.30$

D. APPLICABILITY OF THE FCARS TO CROSS-BORDER TRANSACTIONS

\section{THE TYPES OF FINANCIAL COLLATERAL: CASH, FINANCIAL} INSTRUMENTS AND CREDIT CLAIMS
A. FINANCIAL COLLATERAL
1. What is 'financial collateral'?
2. What is cash?
3. No 'sweep up' wording: sub-mortgages
4. Virtual currencies
B. FINANCIAL INSTRUMENTS
1. What are financial instruments?
2. Financial instruments: Shares in companies
3. Financial instruments: Securities equivalent to shares
4. Financial instruments: Tradeable bonds
5. Financial instruments: Other instruments normally dealt in
6. Financial instruments: Express inclusions
C. CREDIT CLAIMS
1. What are credit claims?
2. Why were credit claims included as financial collateral?
3. A credit claim must arise out of an agreement whereby a credit institution grants credit in the form of a loan
4. Credit claims need not be tradeable

\section{FORMAL REQUIREMENTS DISAPPLIED BY THE FCARS AND EXTENT OF} EXEMPTION FROM THOSE REQUIREMENTS

A. PURPOSE OF THE FINANCIAL COLLATERAL DIRECTIVE

1. Purpose of the Financial Collateral Directive is to limit formal requirements

2. What is meant by the 'provision' of financial collateral?

B. EXEMPTION FROM REGISTRATION AS A CHARGE CREATED BY A COMPANY OR A LIMITED LIABILITY PARTNERSHIP ('LLP')

1. Disapplication of statutory provisions dealing with the registration of charges created by UK companies

2. Transitional provisions relating to charges created by UK companies

3. Disapplication of statutory provisions dealing with the registration of charges created by LLPs

4. Difficulty in relying upon exemption 
C. DISAPPLICATION OF SECTION 4 OF THE STATUTE OF FRAUDS 1677

4.22

1. Disapplication

2. Scope of section 4

3. Significance of disapplication

D. DISAPPLICATION OF SECTION 53(1)(C) OF THE LAW OF PROPERTY ACT 1925

4.27

4.29

4.29

4.31

4.33

4.44

4.44

4.49

4.51

F. DISAPPLICATION OF SECTION 4 OF THE INDUSTRIAL AND PROVIDENT SOCIETIES

ACT 1967 AND SECTION 63 OF THE CO-OPERATIVE AND COMMUNITY BENEFIT

SOCIETIES ACT 2014

4.54

4.54

G. DISAPPLICATION OF SCOTTISH REGISTRATIONS RELATIVE TO BOOK ENTRY SECURITIES COLLATERAL

1. Disapplication

2. Consequences

\section{IMPACT OF UK INSOLVENCY LAW AND BANK RESOLUTION MEASURES AND THE EXTENT TO WHICH THESE ARE DISAPPLIED IN RELATION TO FINANCIAL COLLATERAL ARRANGEMENTS}

A. OBJECTIVES OF THE LEGISLATION

1. Introduction

2. Aims of the Financial Collateral Directive

3. Implementing the Directive in the UK

B. MODIFICATION OF UK INSOLVENCY LAW IN RELATION TO FINANCIAL COLLATERAL ARRANGEMENTS

1. Exclusion of restriction on enforcement of security

2. Exclusion of avoidance of property dispositions

3. Exclusion of power to disclaim onerous property

4. Removal of limitations on floating charges

5. Enforceability where the collateral-taker is not aware of the commencement of winding-up or reorganisation measures

6. Modification of rules on debts in foreign currency

7. Additional protection under Part VII of the Companies Act 1989 and the SFRs

C. UK INSOLVENCY LAW PROVISIONS NOT EXCLUDED BY THE FCARS

1. Protection of creditors

2. Transactions at an undervalue

3. Preferences

4. Parties against whom an order may be made

5. Time limits for challenging a transaction at an undervalue or as a preference

6. Rescission of contracts by the court

7. Transactions defrauding creditors

8. Recognised clearing houses and designated systems

D. IMPACT OF THE SPECIAL RESOLUTION AND INSOLVENCY REGIMES FOR FINANCIAL INSTITUTIONS

1. Overview of regimes established by the Banking Act 2009

2. Stabilisation options under Part 1 of the Banking Act $2009 \quad 5.42$

3. General conditions for exercise of stabilisation options $\quad 5.44$

4. Specific conditions for temporary public ownership or asset management $\quad 5.45$

5. Types of entity against which stabilisation powers may be exercised 5.48

6. Resolution objectives $\quad 5.52$

7. Supplemental, onward or reverse transfer orders 5.53

8. Transfer of securities $\quad 5.54$

9. Property transfers and effect on financial collateral arrangements $\quad 5.56$ 
10. Restrictions on partial property transfers $\quad 5.62$

11. Safeguard for set-off and netting $\quad 5.64$

12. Safeguard for secured liabilities $\quad 5.65$

13. Safeguard for financial markets $\quad 5.66$

14. Remedies for breach of the Safeguard Order $\quad 5.68$

15. Safeguards for trusts $\quad 5.72$

16. Depositor preference and floating charges 5.73

17. Suspension of obligations

18. Restriction on enforcement of security interests $\quad 5.81$

19. Suspension of termination rights and contractual stays

20. Inter-relationship between Part 1 of the BA 2009 and the FCARs 5.89

21. Effect on financial collateral arrangements $\quad 5.92$

22. Bank insolvency under Part 2 of the Banking Act 2009

23. Bank administration under Part 3 of the Banking Act $2009 \quad 5.102$

E. IMPACT OF BAIL-IN AND SAFEGUARDS FOR PROTECTED ARRANGEMENTS

1. Introduction $\quad 5.105$

2. Types of entity to which bail-in will apply $\quad 5.109$

3. Mandatory write-down or conversion of capital instruments $\quad 5.110$

4. Pre-resolution valuation $\quad 5.113$

5. Bail-in as a stabilisation option $\quad 5.114$

$\begin{array}{ll}\text { 6. Priority between creditors } & 5.119\end{array}$

7. Method of bail-in $\quad 5.120$

8. Termination rights and continuity $\quad 5.121$

9. Resolution administrator $\quad 5.123$

10. Exclusions from bail-in $\quad 5.125$

11. Discretionary power of exclusion $\quad 5.126$

12. Safeguard for set-off and netting of 'protected liabilities' $\quad 5.129$

13. Exclusions from the 'protected liabilities' safeguard 5.132

14. Meaning of 'derivative', 'financial contract' and 'qualifying master agreement' $\quad 5.133$

15. Contractual recognition of bail-in $\quad 5.136$

16. Compensation: 'No shareholder or creditor worse off' $\quad 5.137$

F. IMPACT OF OVERSEAS INSOLVENCY PROCEEDINGS

1. EC Insolvency Regulation $\quad 5.138$

2. Insolvency of EEA credit institutions and insurers $\quad 5.149$

3. Cross-border insolvency recognition and cooperation $\quad 5.152$

4. Exclusion of assistance for foreign insolvency proceedings $\quad 5.157$

\section{TITLE TRANSFER FINANCIAL COLLATERAL ARRANGEMENTS}

A. MEANING $\quad 6.01$

1. Definition 6.01

2. Agreements included 6.03

$\begin{array}{ll}\text { 3. Significance } & 6.08\end{array}$

B. RECHARACTERISATION $\quad 6.10$

1. Title transfer financial collateral arrangements to take effect in accordance with
their terms

2. Case law authority on recharacterisation under English law 6.16

3. Market standard terms $\quad 6.31$

C. PURPOSE OF AGREEMENT

1. The meaning of 'to secure or otherwise cover' 6.35

2. Travaux préparatoires $\quad 6.36$

3. Conclusion $\quad 6.38$

D. TRANSFER OF LEGAL AND BENEFICIAL OWNERSHIP

1. Transfer of ownership in original financial collateral 6.39

2. Transfer of ownership in equivalent financial collateral $\quad 6.45$

3. Meaning of 'equivalent financial collateral' $\quad 6.47$

E. NON-NATURAL PERSONS 6.50

1. Implementation of the Financial Collateral Directive 6.50

2. Meaning $\quad 6.55$ 


\section{SECURITY FINANCIAL COLLATERAL ARRANGEMENTS}

A. MEANING OF 'SECURITY FINANCIAL COLLATERAL ARRANGEMENT'

1. Definition

2. Significance

B. PURPOSE

1. Purpose not stated in the Financial Collateral Directive 7.06

2. Obligations owed to the collateral-taker $\quad 7.10$

3. Non-monetary obligations $\quad 7.15$

$\begin{array}{ll}\text { C. SECURITY INTEREST } & 7.21\end{array}$

1. Security interests: Possessory and non-possessory $\quad 7.21$

2. Scottish security interests $\quad 7.25$

3. Security interests arising by operation of law $\quad 7.26$

$\begin{array}{ll}\text { D. 'POSSESSION' OR 'CONTROL' } & 7.31\end{array}$

E. NON-NATURAL PERSONS $\quad 7.32$

8. 'POSSESSION' OR 'CONTROL' TEST TO BE SATISFIED WHEN CREATING A SECURITY FINANCIAL COLLATERAL ARRANGEMENT

A. POSSESSION OR CONTROL TEST $\quad 8.01$

$\begin{array}{lr}\text { 1. Requirement } & 8.01\end{array}$

2. Dispossession $\quad 8.05$

3. Rights of substitution and of withdrawal of excess collateral and the right to collect the proceeds of credit claims

4. Partial definition of 'possession'

B. APPROACH OF THE COURTS TO THE QUESTION OF 'POSSESSION' AND 'CONTROL' $\quad 8.21$

1. The Gray case $\quad 8.21$

2. Lehman Extended Liens case 8.33

3. General principles to be drawn from existing case law 8.37

4. Approach of the courts to the question of 'possession' 8.39

5. Partial definition of 'possession': General $\quad 8.47$

6. Partial definition of 'possession': Account in the name of the collateral-taker $\quad 8.50$

7. Partial definition of 'possession': The proviso $\quad 8.54$

8. Approach of the courts to the question of 'control' 8.63

9. Have the courts conflated the concepts of 'possession' and 'control'?

10. Control and pre-agreed release mechanisms 8.82

11. Can a floating charge ever give the collateral-taker 'possession' or 'control'? $\quad 8.87$

12. Financial collateral held with a third-party custodian $\quad 8.100$

13. Is the question of 'possession' or 'control' to be determined solely at the time that the security financial collateral arrangement is entered into?

C. HOW ARE THE 'POSSESSION' AND 'CONTROL' TESTS TO BE APPLIED TO SPECIFIC

TYPES OF FINANCIAL COLLATERAL ARRANGEMENT?

1. General $\quad 8.116$

2. Legal and equitable mortgages of financial instruments $\quad 8.117$

3. Fixed charges over book entry securities $\quad 8.120$

$\begin{array}{ll}\text { 4. Floating charges over securities } & 8.123\end{array}$

$\begin{array}{ll}\text { 5. Fixed mortgages or charges over cash } & 8.124\end{array}$

$\begin{array}{ll}\text { 6. Mortgages or charges over credit claims } & 8.126\end{array}$

\section{EXTENT TO WHICH A COLLATERAL-PROVIDER MAY BE}

PERMITTED TO EXERCISE RIGHTS ATTACHING TO CHARGED SECURITIES, SUCH AS VOTING RIGHTS AND THE RIGHT TO RECEIVE INCOME, IF THE 'POSSESSION' OR 'CONTROL' TEST IS TO BE SATISFIED

A. BACKGROUND

1. Classification

2. Creation and terms of issue

3. Other considerations 
B. FORMS OF NON-POSSESSORY SECURITY INTEREST

1. Difference between a mortgage and a charge 9.08

2. Difference between a legal and an equitable mortgage $\quad 9.12$

3. Intermediated securities and certificated and uncertificated securities 9.18

C. BUNDLE OF RIGHTS AND OBLIGATIONS WHICH MAY BE THE SUBJECT OF SECURITY 9.25

1. Rights to payment of capital and income $\quad 9.25$

2. Rights to attend and vote at meetings and to vote without a meeting by written resolution

3. Right to determine the value of the financial collateral or the amount of the secured obligations

4. Other rights 9.40

D. CONSEQUENCES OF ALLOWING THE COLLATERAL-PROVIDER TO EXERCISE THE BUNDLE OF RIGHTS BEFORE THE SECURITY IS ENFORCED

1. General

2. First potential problem: Recharacterisation risk

3. Second potential problem: 'Possession' or 'control' test

(a) Shares or other securities: Voting rights and rights to receive distributions of capital and income

(b) Shares or other securities: Rights of valuation, etc

(c) Credit claims: Right to receive repayments of principal and payments of interest

(d) Credit claims: Right to give consents, waivers and variations

\section{CLOSE-OUT NETTING PROVISIONS AND THE FINANCIAL}

\section{COLLATERAL REGULATIONS}

A. RATIONALE FOR, AND MEANING OF, CLOSE-OUT NETTING PROVISIONS

1. Rationale

2. Meaning and scope

3. Power to impose a restriction under the Banking Act 2009

10.07

10.20

B. REGULATION 12 OF THE FINANCIAL COLLATERAL REGULATIONS

10.21

1. Is regulation 12 required at all?

10.21

2. Extent of disapplication under regulation 12(2)

10.29

3. Regulation 12(2): A drafting problem?

4. Interplay between regulation 12 of the FCARs and rules 2.85 and 4.90 of the Insolvency Rules 1986

5. Lehman Firth Rixson case

\section{THE RIGHT OF USE AND THE LEGAL CONSEQUENCES OF ITS EXERCISE, INCLUDING ISSUES OF PRIORITY}

A. INTRODUCTION

1. What is the right of use?

2. Why is the right of use important?

3. When does the right of use arise?

B. RISK TO THE COLLATERAL-PROVIDER IN AGREEING TO THE RIGHT OF USE

1. Loss of the collateral-provider's proprietary claim on an insolvency proceeding affecting the collateral-taker

2. Statutory right of set-off under regulation 16(2) of the FCARs

3. Rights under regulation 16(3) of the FCARs

C. RIGHT OF USE WHERE REGULATION 16 OF THE FINANCIAL COLLATERAL REGULATIONS DOES NOT APPLY

1. Contractual agreement

2. What is a clog on the equity of redemption?

3. Does a right of use granted otherwise than under the FCARs amount to a clog on the equity of redemption?

4. Reform 


\section{REMEDY OF APPROPRIATION}

A. APPROPRIATION

1. Statutory power of appropriation

2. Duty to value collateral and account for any difference in value on appropriation

3. Use of appropriation

4. Appropriation as an alternative to the power of sale or power to appoint a receiver

5. Comparison between appropriation and foreclosure

6. Where a 'power of appropriation' falls outside the scope of the FCARs

7. Appropriation under Scots law

B. TEST CASES ON THE LAW OF APPROPRIATION

1. Cukurova: The facts

2. Preliminary issue of whether the power of appropriation had been effectively exercised
(a) Decision at first instance
(b) Court of Appeal decision
(c) Validity of appropriation upheld by Privy Council

3. Amendment to the statutory power of appropriation

4. Management of the company whose shares are indirectly subject to a disputed appropriation

5. Availability of equitable relief

(a) Alleged collateral purpose and bad faith $\quad 12.51$

(b) Availability of relief from forfeiture

(c) Compatibility with the FCD?

12.55

(d) Question of whether relief should be granted

12.63

(e) Terms of relief

(f) How long does a right to equitable relief survive after appropriation?

(g) Variation to the terms of relief: Extension of time and suspension of further interest

(h) 'Beguiling heresy' and the need for legal certainty

(i) Appraisal of the Privy Council's decision on availability of equitable relief

\section{FINANCIAL COLLATERAL AND THE CONFLICT OF LAWS}

A. INTRODUCTION

B. LAW APPLICABLE TO A FINANCIAL COLLATERAL ARRANGEMENT

1. Law applicable to contractual and non-contractual obligations arising under or in connection with a financial collateral arrangement

2. Law applicable to a voluntary assignment of a claim

3. Proprietary effect of a transfer under a financial collateral arrangement

4. Hague Securities Convention

1. Introduction

2. Contractual aspects

3. Creation and attachment of security, perfection, priority and enforcement

1. Introduction

2. Contractual aspects

3. Effectiveness of transfer

4. Recharacterisation risk

\section{RETROACTIVITY OF THE FINANCIAL COLLATERAL REGULATIONS}
A. INTRODUCTION
1. Coming into force of the Original FCARs, the 2010 Regulations and the BRR Order 14.01
2. When should legislation have retroactive effect?
B. TO WHAT EXTENT ARE THE ORIGINAL FCARS, THE 2010 REGULATIONS AND THE BRR ORDER RETROACTIVE?
1. Dicta in the Lehman Extended Liens case 


\section{PART II USE OF FINANCIAL COLLATERAL}

\section{TAKING AND PERFECTING SECURITY OVER FINANCIAL COLLATERAL}

A. INTRODUCTION

15.01

15.01

1. Preliminary questions to consider

15.02

2. Types of security

B. TAKING SECURITY OVER CASH

C. TAKING SECURITY OVER FINANCIAL INSTRUMENTS

1. Choice of security method

15.10

15.21

15.21

2. Legal mortgage

15.23

15.26

3. Equitable mortgage

15.31

4. Listed and unlisted securities

5. Securities held through a nominee or custodian

6. Risk of the company which is the issuer of the securities becoming a 'subsidiary' or 'subsidiary undertaking' of the collateral-taker

7. Risk to collateral-taker of receiving a financial support direction or a contribution notice under the Pensions Act 2004

8. Risk to collateral-taker of becoming liable to meet calls on members

D. TAKING SECURITY OVER CREDIT CLAIMS

1. Credit claims as financial collateral

2. What the FCD says about credit claims

3. Assignment of credit claims by way of security

4. Notice of assignment

5. Waiver of set-off rights and bank secrecy rules

6. Assignability of credit claims

7. Barbados Trust case

E. SECURITY POWERS OF ATTORNEY

1. Enabling an equitable mortgagee to transfer legal title

2. Reliance on security powers of attorney

3. Revocability of a power of attorney granted by a foreign donor

1. Introduction

2. Objectives

4. Actual or imputed knowledge

5. Constructive notice

15.144

\section{USE OF SECURITIES HELD IN THE CREST SYSTEM AS COLLATERAL}

A. CREST SYSTEM

1. Introduction

2. Direct holding system

3. CREST securities are uncertificated

4. Legislative framework

5. UK CREST securities

6. CREST depository interests (CDIs)

16.13

7. 'Bespoke' depository interests (DIs)

8. Modes of participation in CREST

1. CREST settlement banks distinguished from other collateral-takers

C. CHOICE OF CHARGES FOR COLLATERAL-TAKERS OTHER THAN CREST SETTLEMENT BANKS

1. Legal or equitable mortgage?

2. Position of a legal mortgage holder

3. Position of an equitable mortgage holder 
4. Position of a floating charge holder

16.33

5. Factors which are relevant when choosing type of security

16.36

6. Impact of default rules of a recognised investment exchange or recognised clearing house

7. Title transfer arrangements

8. Conversion of certificated units into uncertificated form

9. Stamp duty reserve tax (SDRT)

16.47

10. Checklist of points to consider when taking a mortgage or charge over uncertificated securities

D. CHARGES HELD BY CREST SETTLEMENT BANKS

16.49

16.50

16.51

1. Role of CREST settlement banks

16.51

2. Collateral security charges

16.58

3. System-charges

4. Use of debit cap to control exposure

5. Secured limits and margin

16.61

16.66

16.67

6. Need for a special method of enforcing charges $\quad 16.69$

7. Use of electronic instructions

16.70

8. 'Fast-track' enforcement procedure

16.73

9. Pre-lodgement of security documents

16.74

16.76

10. Change of user

16.78

11. Constraints

12. Ability to rely on electronic instructions

16.79

13. Importance of the 'fast-track' enforcement procedure

16.87

14. Settlement bank's internal procedures and strategies

16.89

16.91

16.91

1. Implications for collateral-takers

2. Recertification option

16.96

16.98

1. Floating charges and preferential debts where the collateral-taker is not a CREST settlement bank

2. Registration of charges

16.101

3. Negative pledges

16.102

16.103

16.103

16.105

16.108

16.110

16.114

16.114

16.117

16.126

3. Does the second limb of article 3(2) apply to an equitable mortgage?

16.129 security financial collateral arrangement?

5. Does the second limb of article 3(2) apply only to a financial collateral arrangement made between parties eligible under the FCD?

6. Consequences of infringing article 3(2)

16.133

7. Need for greater clarity

16.134

\section{USE OF CLOSE-OUT NETTING AND FINANCIAL COLLATERAL IN RELATION TO DERIVATIVES (INCLUDING ISDA DOCUMENTATION)}

A. INTRODUCTION

1. OTC derivative transactions

2. Master agreements

3. Close-out netting and mark-to-market valuation

4. Financial collateral annexes

5. The International Swaps and Derivatives Association, Inc $\quad 17.20$

$\begin{array}{lr}\text { 6. Clearing of OTC derivative transactions } & 17.28\end{array}$

B. CLOSE-OUT NETTING

1. Close-out netting of OTC derivative transactions - background 
2. How close-out netting works: two basic approaches

3. The difference between close-out netting and set-off

4. The relationship between close-out netting and financial collateral

C. FINANCIAL COLLATERAL IN RELATION TO DERIVATIVES

1. Introduction

2. The ISDA financial collateral forms

17.56

17.56

3. Other ISDA collateral management activities

17.58

4. Financial collateral and clearing of derivatives

18. SPECIAL ISSUES ARISING FROM THE USE OF FINANCIAL COLLATERAL IN REPOS, SECURITIES LENDING AND PRIME BROKERAGE, INCLUDING TREATMENT OF CLIENT ASSETS AND USE OF MARKET STANDARD DOCUMENTATION (OTHER THAN ISDA DOCUMENTATION)

A. WHAT ARE REPOS, SECURITIES LENDING AGREEMENTS AND PRIME BROKERAGE AGREEMENTS AND HOW ARE THEY USED?

1. Repos: What are they?

2. Repos: How are they used?

3. The 2011 GMRA form in more detail

4. Repos: Triparty arrangements

18.04

18.06

5. Securities lending agreements: What are they?

6. Securities lending agreements: How are they used?

7. The 2010 GMSLA form

8. Securities lending by global custodians and settlement systems

18.23

18.26

9. Prime brokerage agreements: What are they?

18.39

18.40

10. Prime brokerage agreements: Common features

18.43

11. Prime brokerage agreements: The FCA's Custody Rules do not establish a statutory trust in relation to custody assets held for a client

12. Prime brokerage agreements: The Client Money Rules establish a statutory trust in relation to client money

13. The nature of the statutory trust that arises in relation to client money

14. Prime brokerage agreements: Trustees of the client money trust have powers of compromise under the Trustee Act 1925

15. Prime brokerage agreements: Security and margin requirement

16. Prime brokerage agreements: Default

17. Prime brokerage agreements: General terms

18. Prime brokerage: Effect of financial crisis in 2007-09

B. SPECIAL ISSUES

1. Does the client retain a proprietary interest in the financial collateral and in the cash deriving from it?

2. Can the prime broker compromise the proprietary interests of clients in the financial collateral by using a scheme of arrangement?

3. Difficulties in dealing with client assets - policy makers' responses
(a) Recovery and resolution plans ('living wills')
(b) The CASS Resolution Pack
(c) The special administration regime ('SAR') and the SAR Review
(d) FCA supervision - the Client Assets Unit
(e) FCA PS14/9 - Review of the client assets regime for investment business
(f) The FCA Client Money Distribution Review

19. USE OF BOOK ENTRY SECURITIES AS COLLATERAL
A. INDIRECT HOLDING SYSTEMS
1. Introduction
2. Indirect holding structures
3. Intermediated securities
4. Immobilised securities
5. Other types of indirect holdings 
6. CSDs and ICSDs

19.11

7. Types of account held by intermediaries

19.13

8. Transfer of book entry securities

19.16

9. Fungibility

19.18

10. Legal structure

19.20

11. No look-through principle

19.25

12. ICSD operated by Euroclear Bank

19.29

13. ICSD operated by Clearstream Banking

19.34

19.37

B. BOOK ENTRY SECURITIES COLLATERAL AND APPLICABLE LAW

19.37

1. Book entry securities collateral

19.40

2. Law applicable to book entry securities collateral

C. TAKING COLLATERAL OVER SECURITIES IN AN INDIRECT HOLDING SYSTEM

19.41

1. General

19.41

2. Need for legal appraisal

19.42

3. Methods of taking collateral in the Euroclear system 19.43

D. SUBSTANTIVE LAW ISSUES TO CONSIDER

1. Core issues

19.50

19.50

2. Nature of an account-holder's rights

19.53

3. Creation of book entry securities

19.54

4. Perfection of book entry securities collateral $\quad 19.55$

5. Priorities

19.56

6. Protection against the intermediary's insolvency 19.57

7. Set-off

19.58

8. Shortfall in a pooled account $\quad 19.61$

9. Upper-tier intermediaries $\quad 19.63$

E. GENEVA SECURITIES CONVENTION

1. Purpose $\quad 19.65$

2. Security interests in intermediated securities $\quad 19.68$

3. Control agreements and designating entries $\quad 19.72$

4. Title transfer collateral $\quad 19.74$

5. Position in relation to third parties $\quad 19.75$

6. Priority of interests granted by an intermediary 19.80

7. Effectiveness in the relevant intermediary's insolvency 19.81

8. Prohibition of upper-tier attachment 19.82

9. Loss sharing in case of the intermediary's insolvency 19.83

10. Protective provisions for collateral transactions $\quad 19.84$

$\begin{array}{lr}\text { 11. Entry into force } & 19.85\end{array}$

\section{USE OF FINANCIAL COLLATERAL IN UK CLEARING HOUSES}

A. RELIANCE ON FINANCIAL COLLATERAL 20.01

$\begin{array}{ll}\text { 1. Regulatory background } & 20.01\end{array}$

2. Collateral requirements 20.06

3. Statutory framework for clearing houses $\quad 20.09$

B. CLEARING AND SETTLEMENT OF TRANSACTIONS $\quad 20.10$

1. Introduction $\quad 20.10$

2. Confirmation of the transaction $\quad 20.11$

3. Clearing of transactions 20.13

4. Central clearing though a CCP $\quad 20.15$

5. Acceptance of a transaction for clearing by a CCP 20.19

$\begin{array}{ll}\text { 6. Novation of the original transaction } & 20.20\end{array}$

$\begin{array}{ll}\text { 7. Open offer route } & 20.21\end{array}$

8. Position of non-clearing firms $\quad 20.23$

$\begin{array}{ll}\text { 9. Client transactions } & 20.26\end{array}$

$\begin{array}{ll}\text { 10. Taking of collateral by a CCP } & 20.27\end{array}$

11. House and client accounts $\quad 20.30$

12. Position netting between the CCP and a clearing member $\quad 20.34$

$\begin{array}{ll}\text { 13. Collateral netting accounts } & 20.37\end{array}$

14. Default management $\quad 20.38$

$\begin{array}{lr}\text { 15. Porting procedure } & 20.39\end{array}$ 
16. Settlement

17. Settlement of securities transactions

18. Central securities depositories

19. Settlement of securities transactions cleared by a CCP

20. Bilateral settlement at the CSD where transactions are not cleared by a CCP

20.47

21. Bilateral settlement on the books and records of a custodian

22. Settlement of derivative contracts

23. Settlement failures

C. COMPARISON BETWEEN TITLE TRANSFER COLLATERAL AND SECURITY COLLATERAL; RIGHT OF USE; SEGREGATED CLIENT ACCOUNTS; DEFAULT MANAGEMENT;

PORTABILITY; AND DEFAULT WATERFALL

1. Differences between title transfer and security types of financial collateral arrangements

. Safeguarding and investment of collateral

3. Right of use by a CCP over collateral

4. Segregation of client accounts

5. Default procedures

6. Portability of client accounts

7. Clearing members providing indirect clearing services

8. Loss-sharing arrangements

9. Return of surplus collateral on client account

D. PART VII PROTECTION FOR RECOGNISED INVESTMENT EXCHANGES AND RECOGNISED CLEARING HOUSES

1. Purpose and territorial extent of protection

2. Scope of 'market contracts' in a recognised investment exchange

3. Scope of 'market contracts' in a recognised clearing house

20.79

4. Scope of 'market charges'

20.80

5. Scope of 'qualifying collateral arrangements' and 'qualifying property transfers'

6. Modification of insolvency law

7. Net sum payable on completion of default proceedings

8. Duty to give assistance

9. Adjustment of prior transactions

20.100

10. Disclaimer of property, rescission of contracts

11. Avoidance of property dispositions

20.102

12. Priorities

20.103

13. Protection of market charges

20.106

14. Default rules

20.109

15. Set-off disapplied in relation to client accounts

20.112

20.113

16. No assistance for foreign insolvency proceedings

20.114

17. Powers of the appropriate regulator to give directions

20.115

18. Use of 'margin' and 'default fund contributions'

20.118

19. Limitations

20.119

E. SETTLEMENT FINALITY

1. Purpose

2. Territorial effect

20.124

3. Insolvency protection

20.125

4. Scope of protection

20.126

5. Effect of system designation

20.127

6. Scope of 'transfer orders'

20.128

7. Scope of 'collateral security'

20.130

8. Protection of collateral security

20.131

9. Overseas protection

20.133

10. Law applicable to securities held as collateral security

20.134

11. Law applicable to a system

20.135

12. Priorities

13. Insolvency proceedings in other jurisdictions

20.137

F. SUMMARY OF COMBINED PROTECTION AGAINST INSOLVENCY RISK 


\section{USE OF CONTRACTUAL SET-OFF AND FLAWED ASSET} ARRANGEMENTS FOR TAKING CASH COLLATERAL

A. INTRODUCTION

21.01

21.01

1. Alternative techniques for taking cash collateral

21.03

21.04

21.06

21.07

21.07

21.08

21.08

21.16

21.21

21.25

21.27

21.27

21.31

21.33

21.34

21.34

21.38

21.41

21.46

21.49

21.55

21.58

21.61

21.63

21.65

21.66

21.66

21.70

21.74

\section{REGULATORY TREATMENT OF FINANCIAL COLLATERAL} ARRANGEMENTS; MARGIN REQUIREMENTS FOR NON-CENTRALLY CLEARED DERIVATIVES; AND REPORTING OF SECURITIES

\section{FINANCING TRANSACTIONS}

A. INTRODUCTION

B. TREATMENT OF FINANCIAL COLLATERAL FOR REGULATORY CAPITAL PURPOSES

1. Introduction

2. Structure of the Capital Requirements Regulation

3. Minimum capital requirements

4. Measurement of credit risk

5. Credit risk mitigation

6. Principles governing the eligibility of credit risk mitigation techniques: need for legal opinions as to enforceability

7. Eligibility: funded credit protection

8. Eligibility: unfunded credit protection

9. Recognition requirements for financial collateral

10. Recognition requirements for third-party deposits and cash assimilated instruments

11. Recognition requirements for receivables

12. Recognition requirements for on-balance sheet netting

13. Recognition requirements for certain master netting agreements

14. Risk weighting and the Financial Collateral Simple Method

15. Maturity mismatches 
16. Treatment of collateral provided to a central counterparty

C. BCBS-IOSCO RULES ON MARGIN REQUIREMENTS FOR NON-CENTRALLY CLEARED DERIVATIVES

1. Introduction

2. Background

3. Scope

4. Areas of national discretion

5. Transfer of initial margin

6. Initial margin threshold

7. When should initial margin be collected?

8. Calculation of initial margin using quantitative models

9. Calculation of initial margin using standardised margin schedule

10. Considerations in respect of methods chosen

11. Use of custodians

12. Rehypothecation and reuse

13. Transfer of variation margin

14. Assets which constitute eligible collateral

15. Haircuts

16. Cross-border issues

22.106

17. Timeline for phase-in: variation margin

22.108

18. Timeline for phase-in: initial margin

19. Impact of the BCBS-IOSCO Framework

22.111

20. EU regime

22.114

21. Scope of the EU regime

D. SIGNIFICANT DIFFERENCES FROM BCBS-IOSCO FRAMEWORK

1. Cross-currency haircut

2. Calculation and collection of initial margin

3. Segregation of initial margin

4. Rehypothecation

5. Concentration limits

6. Intra-group transactions

7. Phase-in schedule

22.131

22.135

E. EUROPEAN SECURITIES FINANCING TRANSACTIONS REGULATION

1. Introduction

22.136

2. FSB policy framework on securities financing transactions

22.141

3. To whom will the SFTR apply?

22.145

4. How are SFTs defined?

5. Requirement to report SFTs to a trade repository

6. Disclosure to investors in funds

7. SFTR: preconditions of reuse

22.156

22.159

8. Administrative sanctions

9. Entry into force, transitional provisions and review

\section{SCOTTISH LAW PERSPECTIVE ON THE FINANCIAL COLLATERAL REGULATIONS AND THEIR APPLICATION}

A. SCOTTISH LEGAL SYSTEM

1. Separate Scottish legal system

2. No equitable interests in Scots law

B. TRANSFER OF AND FIXED SECURITY OVER FINANCIAL COLLATERAL IN SCOTS LAW

1. Creating fixed security by ownership transfer

2. Categories of financial collateral

3. Cash, credit claims and residual financial instruments

4. Bearer securities

5. Registered securities

6. Uncertificated securities

7. Intermediated securities

8. Reform

C. FLOATING CHARGES 
E. SET-OFF, FLAWED ASSETS AND NETTING $\quad 23.28$

F. INSOLVENCY $\quad 23.36$

1. Corporate and partnership insolvency 23.36

$\begin{array}{ll}\text { 2. Partnership insolvency } & 23.37\end{array}$

3. Corporate insolvency 23.39

4. Preferences and undervalue transactions $\quad 23.41$

G. FCARs AND SCOTS LAW $\quad 23.47$

1. General status of the FCARs in Scotland $\quad 23.47$

2. Effects of the FCARs in Scotland $\quad 23.49$

3. Specific Scottish issues on the FCARs $\quad 23.50$

24. LAW REFORM

A. INTRODUCTION

B. PROPOSAL FOR EU LEGISLATION ON THE HOLDING AND DISPOSITION OF SECURITIES

1. Consultation document $\quad 24.02$

2. Objectives of the proposed legislation $\quad 24.05$

3. Account-held securities $\quad 24.08$

4. Methods for acquisition and disposition $\quad 24.10$

5. Legal effectiveness of acquisitions and dispositions $\quad 24.12$

6. Effectiveness in insolvency 24.13

7. Priority of competing interests $\quad 24.14$

8. Protection of account holders in case of insolvency of an account provider $\quad 24.20$

$\begin{array}{ll}\text { 9. Instructions to intermediaries } & 24.21\end{array}$

10. Attachment by a creditor of an account holder $\quad 24.22$

11. Attachment by a creditor of an account provider $\quad 24.23$

12. Conflict of laws $\quad 24.25$

13. Cross-border recognition of rights attached to securities $\quad 24.28$

$\begin{array}{ll}\text { 14. Passing on information } & 24.29\end{array}$

15. Facilitation of the ultimate account-holder's position $\quad 24.30$

16. Non-discriminatory charges $\quad 24.32$

C. BUILDING A EUROPEAN CAPITAL MARKETS UNION $\quad 24.33$

$\begin{array}{ll}\text { 1. Objective } & 24.33\end{array}$

2. Market infrastructure $\quad 24.36$

3. Collateral $\quad 24.37$

4. Securities law $\quad 24.38$

5. Insolvency law $\quad 24.39$

6. Next steps $\quad 24.40$

D. LAW COMMISSION REPORT ON COMPANY SECURITY INTERESTS $\quad 24.41$

$\begin{array}{ll}\text { 1. Background to the Report } & 24.41\end{array}$

2. Recommendations regarding financial collateral $\quad 24.48$

E. REFORM OF ENGLISH LAW OF SECURITY $\quad 24.55$

1. Secured Transactions Law Reform Project 24.55

2. Secured transactions law review by the City of London Law Society 24.58

F. NULLIFICATION OF CLAUSES RESTRICTING THE ASSIGNMENT OF RECEIVABLES $\quad 24.62$

1. Should there be a statutory provision rendering ineffective any contractual restriction on the assignment of a receivable?

2. Statutory power under the Small Business, Enterprise and Employment Act 2015 to invalidate restrictions on assignment of receivables

3. Draft regulations under the Small Business, Enterprise and Employment Act 2015 and DBIS Summary of Responses

4. Conclusion 24.93

G. REFORM OF SCOTS LAW OF SECURITY $\quad 24.94$

$\begin{array}{ll}\text { 1. Proposal for a new fixed security interest } & 24.94\end{array}$

H. UNCITRAL MODEL LAW ON SECURED TRANSACTIONS $\quad 24.96$ 
Appendix 1: Shortcomings and uncertainties of the FCARs

Appendix 2: Texts of the Financial Collateral Directive and Financial Collateral Regulations, as amended

Appendix 3: Travaux Préparatoires for Directive 2002/47/EC of 6 June 2002

Glossary of terms 